\title{
Advances in Pediatric Pulmonary Arterial Hypertension
}

\author{
Dunbar Ivy, MD \\ The Children's Hospital Heart Institute, Children's Hospital Colorado, University of Colorado \\ Denver School of Medicine, Aurora, Colorado, USA
}

\begin{abstract}
Purpose of Review-Pulmonary arterial hypertension (PAH) is an important cause of morbidity and mortality in children. Approved medications for the treatment of adult PAH have been used to treat children but evidence based treatment algorithms for children are lacking.

Recent Findings-Pediatric PAH registries have begun to define the incidence and prevalence of idiopathic PAH and PAH associated with congenital heart disease. A pediatric specific classification of pulmonary hypertensive vascular disease has been proposed. Furthermore, the first randomized placebo-controlled trial of type-5 phosphodiesterase therapy in treatment naïve children with PAH has been completed and reported. This trial highlights the importance of the difficulties of performing clinical trials children with targeted PAH therapy as well as the importance of long-term follow-up of adverse events.
\end{abstract}

Summary-Classification, clinical trials, and therapy for children with PAH must take into account the unique aspects of PAH in children.

\section{Keywords}

Pulmonary Hypertension; Children; Endothelin Receptor Antagonists; Phosphodiesterase-5; Prostacyclin

\section{Introduction}

Diagnosis and treatment of children with pulmonary arterial hypertension (PAH) lags behind the understanding and treatment of this disorder in adults. Although advances in therapy have led to improved survival for many forms of PAH, there remains no cure for some, including Idiopathic PAH (IPAH). The off-label application of adult pulmonary hypertension specific therapies to children has broadened the available options for therapy. Selection of appropriate therapies for pulmonary hypertension is complex and must be carefully chosen according to the etiology and pulmonary vasoreactivity testing during cardiac catheterization. This review highlights the recent advances in pediatric $\mathrm{PH}$ classification and therapy.

This is a PDF file of an unedited manuscript that has been accepted for publication. As a service to our customers we are providing this early version of the manuscript. The manuscript will undergo copyediting, typesetting, and review of the resulting proof before it is published in its final citable form. Please note that during the production process errors may be discovered which could affect the content, and all legal disclaimers that apply to the journal pertain. 


\section{Definition and Classification}

PAH is defined as a mean pulmonary artery pressure (PAP) $\geq 25 \mathrm{mmHg}$ at rest, with a normal pulmonary capillary wedge pressure $(\leq 15 \mathrm{mmHg})$ and increased pulmonary vascular resistance index $\left(\geq 3\right.$ Wood units $\left.\mathrm{x} \mathrm{m}^{2}\right)$.(1) Classifying pediatric $\mathrm{PH}$ according to the WHO classification (Table 1) is problematic as many children with $\mathrm{PH}$ have associated comorbidities and syndromes.(2) A working group of the Pulmonary Vascular Research Institute developed a classification specific to children (Table 2).(3) In particular, this classification recognized the concepts of the contribution of abnormalities of lung growth and development to pediatric PH. PH can develop in utero or can be superimposed on key periods of lung development leading to life-long airway and pulmonary vascular abnormalities. Pediatric pulmonary hypertensive vascular disease has been divided into 10 broad categories. Many children presenting with PH have heterogeneous disease consisting of varying predisposing factors, including prematurity, a chromosomal or genetic anomaly, congenital heart disease, and sleep disordered breathing. PH associated with bronchopulmonary dysplasia has been highlighted in this classification. For children with a biventricular circulation, the definition is similar to adults; however, the Panama classification specifically includes children with PH in the setting of single ventricle physiology after a cavopulmonary anastomosis. In this setting, pediatric pulmonary hypertensive vascular disease is defined as a pulmonary vascular resistance index $>3.0$ Wood units $\mathrm{X} \mathrm{m}^{2}$ or a transpulmonary gradient $>6 \mathrm{mmHg}$.(3) This classification was not designed to determine use of targeted PH therapy but rather an aid in classification and assessment of children with PH.

\section{Epidemiology and Survival}

Large registries of pediatric PH have recently been published, shedding light on the incidence and prevalence of $\mathrm{PH}$ in children as well as the general demographics. These registries include the Swiss Registry (4), the United Kingdom PH service (5), the French PH registry (6), the Netherlands PH registry (7), the TOPP registry (Tracking Outcomes in Pediatric Pulmonary Hypertension)(8), and finally the US REVEAL (Registry to EValuate Early And Long-Term PAH Disease Management) registry.(9)

The most common causes of transient PH the Netherlands registry was persistent pulmonary hypertension of the newborn and pulmonary hypertension associated with repair of "flow" CHD with resolution of the PH after surgery, with an incidence of 30.1 and 21.9 cases per million children, respectively (Figure 1).(7) IPAH and PAH associated with congenital heart disease (APAH-CHD) account for the majority of progressive forms of $\mathrm{PH}$ in the pediatric registries. IPAH accounts for 35-60\% of patients in these registries with most studies having $50-60 \%$ of patients with IPAH. $(4,6,7,9)$ PAH associated with CHD is the second most cause of PAH in these registries accounting for $24-52 \%$ of patients. The incidence of IPAH in the national registries from the United Kingdom and Netherlands was 0.48 and 0.7 cases per million with a point prevalence of 2.1 and 4.4 cases per million, respectively. $(7,10)$ The incidence and point prevalence of APAH-CHD was 2.2 and 15.6 cases per million in the Netherlands registry.(7) Bronchopulmonary dysplasia is likely under-represented in these series and accounts for $12-13 \%$ of patients. $(4,8)$ Syndromes are common in pediatric $\mathrm{PH}$ practice, with Trisomy 21 being the most common syndrome. $(7,9)$

The most frequent presenting symptom of PH was dyspnea in most series (53\% IPAH/ familial pulmonary arterial hypertension (FPAH); 30\% APAH-CHD). However, presyncope/syncope was more frequent in IPAH/FPAH (36\%) than APAH-CHD (4\%). Although survival in pediatric $\mathrm{PH}$ has markedly improved over the last 2 decades, data from these registries still show the need for improvement. The 1,3 and 5 year survival for 64 
children with IPAH in the U.K. Service was $89 \%, 84 \%$ and $75 \%$. (10) The U.S. REVEAL registry included 199 pediatric patients, of which 122 were diagnosed with IPAH/familial $\mathrm{PAH}$ and 77 with APAH-CHD. Five-year survival from diagnostic right heart catheterization was similar for IPAH/FPAH and APAH-CHD (75\% $\pm 7 \%$ vs. $71 \% \pm 14 \%$, respectively).(9) Factors associated with a worse prognosis include WHO functional class $\mathrm{III} / \mathrm{IV}$, poor height and weight $\mathrm{z}$-score at presentation, older age at presentation, specific diagnoses (pulmonary veno-occlusive disease, pulmonary capillary hemangiomatosis, FPAH), and hemodynamic variables such as lower mixed venous oxygen saturation and higher PVRI. (7, 9, 10) Survival of children with Eisenmenger syndrome appeared worse than reported in adults.(7) Although the overall survival in the UK service was similar for IPAH and APAH-CHD, patients with repaired CHD had the worst prognosis in 2 series (Figure 2). $(5,7)$

\section{Therapy of PAH}

Based on understanding of abnormalities of the vascular endothelium, three classes of drugs have been studied for the treatment of PAH: prostanoids (epoprostenol, treprostinil, iloprost), endothelin receptor antagonists (bosentan, ambrisentan), and phosphodiesterase inhibitors (sildenafil, tadalafil) $(11,12)(13)$. Similarities in the pathobiology of PAH have led to similar treatment algorithms, in children $(14,15)$ (Figure 3 ) and adults (16)(Figure 4). However, as previously described, abnormalities of lung development are common in children with PAH, and infants and young children cannot be classified in the adult WHO functional classification. A pediatric classification has been developed, but PAH therapies have not been stratified to this classification (17).

Cardiac catheterization is an important initial step in the treatment of children with PAH, because it aids in ruling out associated disease states, such as pulmonary vein disease, and allows for determination of vasoreactivity, which is necessary to determine if calcium channel blocker therapy may be appropriate. The younger the child at the time of testing, the greater the likelihood of acute pulmonary vasodilation in response to vasoreactivity testing $(18,19)$. Many inhaled vasodilators have been used for vasoreactivity testing of vasodilator (20-23). The conventional pediatric definition of a positive response to vasodilators is a fall in mean PAP and PVRI by $20 \%$ with no significant change or an increase in cardiac index. The adult PH community has embraced a more strict definition as a fall in mean PAP of at least $10 \mathrm{mmHg}$ to near normal levels to less than a mean PAP of $40 \mathrm{mmHg}(11,24)$. The most appropriate definition for children is not known. Catheterization in children is safer than previous decades using skilled cardiologists and anesthetists comfortable with these ill patients, but patients with suprasystemic PH pose particular risk. (25-27) Rarely cardiac catheterization may be briefly delayed for patient stabilization before catheterization is performed.

\section{Calcium channel blockers}

Treatment of PAH with calcium channel blockers is decreasing with the approval of more targeted therapy, and is limited to select patients with a positive acute vasodilator challenge. $(12,28)$ Elevated right atrial pressure and low cardiac output are contraindications to chronic calcium channel blockade. Although the exact definition of vasoreactivity in children to determine acceptability of calcium channel blockade is not known, marked reactivity with near normalization of pulmonary artery pressure is a common feature. Patients who do not have an acute vasodilatory response to short acting agents and who are then placed on calcium channel blocker therapy are likely to deteriorate (11). It is estimated that $60-80 \%$ of children with severe $\mathrm{PH}$ are non-responsive to acute vasodilator testing, and therefore require therapy other than calcium channel antagonists. 


\section{Prostacyclins}

Epoprostenol, synthetic prostacyclin, is the only therapy shown to improve survival in adults. $(29,30)$ Therapy with prostacyclin and its analogues has been extrapolated for use in children. Long-term IV epoprostenol has improved survival for children with PAH with a 4year survival rate of $94 \%$ in IPAH (28), and a 10-year treatment success rate (freedom from death, transplantation, or atrial septostomy) of 37\% (19). Epoprostenol has a short half-life rendering a continuous intravenous infusion with a permanent central venous catheter necessary. Complications such as line sepsis, local infection and catheter dislodgement are not unusual and can be responsible for life-threatening rebound PH (31). Recently, the use of specific closed hub systems has been shown to decrease the infection rate (32). Although uncommon, children with a dramatic sustained response to epoprostenol may be weaned to oral or inhaled therapy if hemodynamics return to near normal values. $(33,34) \mathrm{A}$ room temperature formulation is FDA approved for use in adults, but has not been studied in children.

Iloprost is an inhaled prostacyclin analogue with a longer half-life (35). In children treated with iloprost, WHO functional class has been shown to be improved in 35\%, remained unchanged in 50\% and decreased in 15\% (36). Lower-airway reactivity is a problem in some children, as well as poor compliance with the need for frequent aerosol administrations (6-8 times daily). Iloprost has been used in postoperative congenital heart disease associated with PH (37) and has been shown to be as efficacious in lowering mean PVR and improve systemic oxygen saturation compared to NO (22). Nevertheless, clinical deterioration, side effects, and poor compliance limit its chronic administration in children (36).

Treprostinil, a prostacyclin analogue, is approved by the FDA for subcutaneous use (2002), intravenous administration (2004) and inhalation (2009). Subcutaneous treprostinil has been shown to improve exercise tolerance and hemodynamics in adult patients with PAH (38). Discomfort at the infusion site is common and represents the most limiting factor. However, a recent study of subcutaneous treprostinil in young children showed promise with tolerable side effects.(39) Similar to epoprostenol, intravenous treprostinil requires central line access and continuous infusion, but is easier for families to mix, has a longer half-life, and may allow use of a smaller pump. Intravenous treprostinil has fewer side effects than intravenous epoprostenol, but there are no studies comparing efficacy. (40) Treprostinil in an inhaled form is increasing in usage. (41)

\section{Endothelin}

Blockade of the receptors of ET-1, a potent vasoconstrictor peptide, with bosentan lowers pulmonary artery pressure and resistance, and improves exercise tolerance in adults with PAH (42). Although bosentan is not approved for use in children with PAH in the US, several studies have suggested safety and a delay in disease progression (43-48). A retrospective study of 86 children on bosentan for a median exposure of 14 months with and without concomitant therapy found that bosentan provided a sustained clinical and hemodynamic improvement was overall well tolerated, and two year survival estimates were $91 \%$ (47). Follow-up of these patients at 4 years revealed the Kaplan-Meier estimate of disease progression in patients while on bosentan was $54 \%$ with a survival estimate of $82 \%$. (49) In a cohort of children with IPAH and APAH-CHD, the Kaplan-Meier survival estimates for 101 patients treated with bosentan as part of an overall targeted PH strategy were $96,89,83$ and $60 \%$ at 1, 2, 3 and 5 yrs., respectively. (48) In 146 children with PAH, elevated transaminase levels were reported in $2.7 \%$ of children compared with $7.8 \%$ of patients aged $\geq 12$ years, and the overall discontinuation rate from bosentan was $14 \%$ in children compared with $28 \%$ in patients aged $\geq 12$ years.(45) The prospective FUTURE-1 
trial treated children with a pediatric specific water-dissolvable formulation at doses of 2 $\mathrm{mg} / \mathrm{kg} / \mathrm{dose}$ and $4 \mathrm{mg} / \mathrm{kg} /$ dose twice daily. There was no difference in drug exposure, and plasma concentrations did not reach adult levels with either dose. There were no abnormalities of liver function testing leading to a general recommendation of the $2 \mathrm{mg} / \mathrm{kg} /$ dose twice daily for children.(50) Bosentan has been studied in Eisenmenger syndrome in a placebo-controlled trial in patients. Bosentan was well tolerated and improved exercise capacity and hemodynamics without compromising peripheral oxygen saturation. (51) Bosentan, and other advanced therapies, have been associated with improved survival in adults with Eisenmenger syndrome.(52) (Figure 5) A specific pediatric formulation has been recently approved in Europe.

Ambrisentan is a once-daily selective $\mathrm{ET}_{\mathrm{A}}$ endothelin receptor-antagonist that was FDA approved in 2007 for use in adults. In March 2011 ,monthly liver transaminase monitoring was no longer mandated, but many programs continue regular monitoring every few months. Adults showed significant improvements in 6-minute walk distance and significant delay in clinical worsening on ambrisentan.(53). Studies in children suggest that some patients treated with bosentan may show additional improvement on transition to ambrisentan. (54)

\section{Phosphodiesterase-5 inhibitors}

Sildenafil and tadalafil, are specific phosphodiesterase-5 inhibitors $(5,55-58)$, which promote an increase in cGMP levels and thus promote pulmonary vasodilation. Sildenafil may also be useful in the setting of inhaled nitric oxide therapy withdrawal (59) in postoperative PH (60), or in the presence of PH related to chronic lung disease.(57) In a 16week, randomized, double-blind study of treatment naïve children, (STARTS-1), the effects of oral sildenafil in pediatric PAH were studied.(61) Children ( $\mathrm{n}=234)$ with PAH (aged 1-17 yrs.; $\geq 8 \mathrm{~kg}$ ) received low-, medium-, or high-dose sildenafil or placebo orally three times daily. The primary comparison was percent change in peak oxygen consumption $\left(\mathrm{pVO}_{2}\right)$ for the three sildenafil doses combined from baseline to week 16; exercise testing was performed only in children able to exercise reliably. Secondary endpoints, including mean PAP, PVRI, and functional class, were assessed in all enrolled patients, including those unable to reliably exercise. The estimated mean \pm standard error percentage change in $\mathrm{pVO}_{2}$ for the low-, medium- and high-doses combined versus placebo was $7.7 \% \pm 4.0 \%$ (95\% CI, $-0.2 \%$ to $15.6 \% ; P=0.056$ )(Figure 6). Peak $\mathrm{VO}_{2}, \mathrm{FC}$, mPAP, and PVRI improved with the medium- and high-dose groups versus placebo, whilst the low dose was ineffective. Upper respiratory tract infections, pyrexia, and vomiting occurred more often with sildenafil than placebo.(61) A long-term extension study included children continued on sildenafil monotherapy. For the first two years survival on sildenafil monotherapy was the same for all dosage groups. (Table 3) At three years, an increase in mortality was noted in the high-dose group compared to the low dose group, and the data safety monitoring board requested to decrease the dose of any child receiving high dose. Deaths in the extension study were related to etiology and baseline disease severity. The majority of deaths occurred in patients with IPAH/FPAH. Of patients who died, most had baseline values above median values for PVRI, mean pulmonary artery pressure, and right atrial pressure. Sildenafil is approved for use in children with PAH in Europe: $10 \mathrm{mg}$ t.i.d. in patients up to $20 \mathrm{~kg}$, and $20 \mathrm{mg}$ t.i.d. in heavier patients, but sildenafil is not approved for children with PAH in the U.S.

Intravenous sildenafil has been shown to potentiate the increase in cGMP in response to NO in children with increased PVR related to CHD or in the post-operative state. Nevertheless, sildenafil infusion may be associated with increased intrapulmonary shunting and augmentation of hypoxemia related to V/Q mismatch in the postoperative CHD patient.(62, 63) However, a recent study of intravenous sildenafil has shown improvement in oxygenation index in persistent pulmonary hypertension of the newborn in patients treated 
with or without inhaled nitric oxide.(64) To evaluate the efficacy and safety of intravenous sildenafil for postoperative pulmonary hypertension in pediatric patients undergoing congenital heart surgery, a double-blind, multicenter, placebo-controlled, dose-ranging, parallel-group trial was conducted. Although the study was terminated after 15 months due to slow patient accrual, seventeen patients were randomized and treated, five with placebo and four each with low-, medium-, and high-dose sildenafil. In the first $24 \mathrm{~h}, 40 \%$ of placebo and $17 \%$ of sildenafil patients required additional therapy $(p=0.330)$. Median time to extubation ( 3 versus 8 days, $\mathrm{p}=0.023$ ) and intensive care unit stay ( 6 versus 15 days, $\mathrm{p}=$ 0.008 ) were shorter for sildenafil patients. No adverse events or systemic hypotension were attributed to sildenafil.(65)

Other PDE-5 inhibitors, such as tadalalfil, have been recently studied leading to US FDA approval in 2009. (66). Tadalafil, dosed daily may improve compliance and appears to have a similar hemodynamic profile to sildenafil in children. $(67,68)$ In 14 of 29 children transitioned from sildenafil to tadalafil, repeat cardiac catheterization showed statistically significant improvements in mean pulmonary arterial pressure $(\mathrm{mmHg})(53.2+/-18.3$ versus $47.4+/-13.7, \mathrm{p}<0.05)$ and pulmonary vascular resistance index (unitsxm2) $(12.2+/-7.0$ versus $10.6+/-7.2, \mathrm{p}<0.05)$. (68)

\section{Novel Therapies}

Therapies targeting remodeling of the pulmonary vasculature are under study.(12) Imatinib, an antagonist of the platelet-derived growth factor (PDGF) receptor, is approved for the treatment of chronic myeloid leukemia. PDGF contributes to vascular remodeling and participates in mytogenic signaling and smooth muscle cell recruitment. Case reports of the use of imatinib for patients with severe PAH refractory to all available treatment showed clinical and hemodynamic improvement (69) with further promising results in a Phase II trial (70)

Bone-derived endothelial progenitor cells (EPCs) normally function to repair and regenerate blood vessels. Regeneration of lung vascular endothelium by injection of progenitor cells may represent a novel treatment paradigm for patients with $\mathrm{PAH}$; trials are underway in Canada $(71,72)$. Other targets in the future may include blockade of stem cell populations contributing to the fibroproliferative process, such as fibrocytes.(73)

Novel agents leading to pulmonary vasodilation are being developed. Riociguat, a direct oral soluble guanylate cyclase (sGC) stimulator, increases cGMP directly in a non-NO dependent manner but also increases the sensitivity of sGC to NO; Phase III trials are currently underway. (74-77) Selexipag is an orally available prostacyclin receptor (IP receptor) agonist that is chemically distinct from $\mathrm{PGI}_{2}$ and is in clinical development for the treatment of pulmonary arterial hypertension in Phase III trials. Where prostacyclin and its analogs can activate prostanoid receptors other than the IP receptor, direct stimulation of these receptors may help minimize gastric side effects such as nausea and vomiting. (78) Novel endothelin receptor antagonists are currently under study in Phase III trials as well. Macitentan is a highly potent, tissue-targeting dual $\mathrm{ET}_{\mathrm{A}}, \mathrm{ET}_{\mathrm{B}}$ receptor antagonist.(79)

\section{Conclusions}

Pulmonary arterial hypertension (PAH) is a life-threatening disease whose prognosis has changed dramatically over the past decade since the introduction of new therapeutic agents as well as the off-label application of adult pulmonary hypertension specific therapies to children. Therapy in adults is evidence based on randomized, placebo-controlled trials. However, therapy in children is based on experience. Future clinical trials must take into 
account the unique aspects of PAH in children, including pharmacokinetics, clinical endpoints, and long-term toxicity.

\section{Acknowledgments}

This work was supported in part by the National Institutes of Health (NIH) Specialized Centers of Clinically Oriented Research grant HL-HL684923, NIH/NCRR Colorado CTSI Grant Number UL1 RR025780, the Jayden DeLuca Foundation and the Leah Bult Pulmonary Hypertension Fund.

The University of Colorado Denver School of Medicine receives fees from Actelion, Gilead, Pfizer, and United Therapeutics for Dr Ivy to be a consultant. Dr Ivy serves on the Gilead Sciences Research Scholars Program in Pulmonary Hypertension review panel.

\section{References}

1. Simonneau G, Robbins IM, Beghetti M, Channick RN, Delcroix M, Denton CP, et al. Updated clinical classification of pulmonary hypertension. J Am Coll Cardiol. Jun 30; 2009 54(1 Suppl):S43-54. [PubMed: 19555858]

2. van Loon RL, Roofthooft MT, van Osch-Gevers M, Delhaas T, Strengers JL, Blom NA, et al. Clinical characterization of pediatric pulmonary hypertension: complex presentation and diagnosis. J Pediatr. Aug; 2009 155(2):176-82. e1. [PubMed: 19524254]

3. Cerro MJ, Abman S, Diaz G, Freudenthal AH, Freudenthal F, Harikrishnan S, et al. A consensus approach to the classification of pediatric pulmonary hypertensive vascular disease: Report from the PVRI Pediatric Taskforce, Panama 2011. Pulm Circ. 2011; 1(2):286-98. [PubMed: 21874158] ** Novel pediatric specific classification that emphasizes the heterogeneity of pediatric $\mathrm{PH}$ and the importance of the deleoping lung.

4. Fasnacht MS, Tolsa JF, Beghetti M. The Swiss registry for pulmonary arterial hypertension: the paediatric experience. Swiss Med Wkly. Sep 8; 2007 137(35-36):510-3. [PubMed: 17990138]

5. Haworth SG, Hislop AA. Treatment and survival in children with pulmonary arterial hypertension: the UK Pulmonary Hypertension Service for Children 2001-2006. Heart. Apr; 2009 95(4):312-7. [PubMed: 18952635]

6. Fraisse A, Jais X, Schleich JM, di Filippo S, Maragnes P, Beghetti M, et al. Characteristics and prospective 2-year follow-up of children with pulmonary arterial hypertension in France. Arch Cardiovasc Dis. Feb; 2010 103(2):66-74. [PubMed: 20226425]

7. van Loon RL, Roofthooft MT, Hillege HL, Ten Harkel AD, van Osch-Gevers M, Delhaas T, et al. Pediatric Pulmonary Hypertension in the Netherlands: Epidemiology and Characterization During the Period 1991 to 2005. Circulation. Sep 26.2011 124:1755-64. [PubMed: 21947294] * Largest series of patients in a national study with description of incidence and prevalence of transient and progressive $\mathrm{PH}$.

8. Berger RM, Beghetti M, Humpl T, Raskob G, Ivy DD, Jing ZC, et al. Clinical Features of Pediatric Pulmonary Hypertension: The Global Registry Tracking Outcomes and Practice in Pediatric Pulmonary Hypertension (TOPP). Lancet. 2011 In Press. ** Baseline demographics of PH in a large worldwide registry of pediatric $\mathrm{PH}$

9. Barst RJ, McGoon MD, Elliott CG, Foreman AJ, Miller DP, Ivy DD. Survival in Childhood Pulmonary Arterial Hypertension: Insights From the Registry to Evaluate Early and Long-term PAH Disease Management. Circulation. 2011 In Press. *Series of 216 patients followed prospectively as part of the U.S. REVEAL registry describing a 5 year survival from diagnosis of $74 \%$.

10. Moledina S, Hislop AA, Foster H, Schulze-Neick I, Haworth SG. Childhood idiopathic pulmonary arterial hypertension: a national cohort study. Heart. Sep; 2010 96(17):1401-6. [PubMed: 20406768]

11. Barst RJ, Gibbs JS, Ghofrani HA, Hoeper MM, McLaughlin VV, Rubin LJ, et al. Updated evidence-based treatment algorithm in pulmonary arterial hypertension. J Am Coll Cardiol. Jun 30; 2009 54(1 Suppl):S78-84. [PubMed: 19555861] 
12. Ivy, DD.; Rashid, A. Chronic Pulmonary Hypertension. In: Munoz, R.; Morell, V.; da Cruz, E.; Vetterly, C Carol, editors. Critical Care of Children with Heart Disease: Basic Medical and Surgical Concepts. Springer-Verlag; London: 2010. p. 483-505.

13. Barst RJ, Ertel SI, Beghetti M, Ivy DD. Pulmonary arterial hypertension: a comparison between children and adults. Eur Respir J. Mar; 2011 37(3):665-77. [PubMed: 21357924]

14. Tissot C, Ivy DD, Beghetti M. Medical therapy for pediatric pulmonary arterial hypertension. J Pediatr. Oct; 2010 157(4):528-32. [PubMed: 20656296] *Updated alogrithm for pediatric PAH treatment

15. Abman SH, Ivy DD. Recent progress in understanding pediatric pulmonary hypertension. Current opinion in pediatrics. Jun; 2011 23(3):298-304. [PubMed: 21572384]

16. Galie N, Hoeper MM, Humbert M, et al. Guidelines for the diagnosis and treatment of pulmonary hypertension: the Task Force for the Diagnosis and Treatment of Pulmonary Hypertension of the European Society of Cardiology (ESC) and the European Respiratory Society (ERS), endorsed by the International Society of Heart and Lung Transplantation (ISHLT). Eur Heart J. Oct; 2009 30(20):2493-537. [Practice Guideline]. [PubMed: 19713419]

17. Lammers AE, Adatia I, Cerro MJ, Diaz G, Freudenthal AH, Freudenthal F, et al. Functional classification of pulmonary hypertension in children: Report from the PVRI pediatric taskforce, Panama 2011. Pulm Circ. Aug 2; 2011 1(2):280-5. [PubMed: 21874157]

18. Barst RJ. Pharmacologically induced pulmonary vasodilatation in children and young adults with primary pulmonary hypertension. Chest. Apr; 1986 89(4):497-503. [PubMed: 2869919]

19. Yung D, Widlitz AC, Rosenzweig EB, Kerstein D, Maislin G, Barst RJ. Outcomes in children with idiopathic pulmonary arterial hypertension. Circulation. Aug 10; 2004 110(6):660-5. [PubMed: 15289375]

20. Atz AM AI, Lock JE, et al. Combined effects of nitric oxide and oxygen during acute pulmonary vasodilator testing. Journal American College of Cardiology. March 1; 1999 33(3):813-9. 1999.

21. Balzer DT, Kort HW, Day RW, Corneli HM, Kovalchin JP, Cannon BC, et al. Inhaled Nitric Oxide as a Preoperative Test (INOP Test I): the INOP Test Study Group. Circulation. Sep 24; 2002 106(12 Suppl 1):I76-81. [PubMed: 12354713]

22. Rimensberger PC, Spahr-Schopfer I, Berner M, Jaeggi E, Kalangos A, Friedli B, et al. Inhaled nitric oxide versus aerosolized iloprost in secondary pulmonary hypertension in children with congenital heart disease: vasodilator capacity and cellular mechanisms. Circulation. Jan 30; 2001 103(4):544-8. [PubMed: 11157720]

23. Barst RJ, Agnoletti G, Fraisse A, Baldassarre J, Wessel DL. Vasodilator testing with nitric oxide and/or oxygen in pediatric pulmonary hypertension. Pediatr Cardiol. Jul; 2010 31(5):598-606. [PubMed: 20405117]

24. Badesch DB, Champion HC, Sanchez MA, Hoeper MM, Loyd JE, Manes A, et al. Diagnosis and assessment of pulmonary arterial hypertension. J Am Coll Cardiol. Jun 30; 2009 54(1 Suppl):S5566. [PubMed: 19555859]

25. Carmosino MJ, Friesen RH, Doran A, Ivy DD. Perioperative complications in children with pulmonary hypertension undergoing noncardiac surgery or cardiac catheterization. Anesth Analg. Mar; 2007 104(3):521-7. [PubMed: 17312201]

26. Friesen RH, Williams GD. Anesthetic management of children with pulmonary arterial hypertension. Paediatr Anaesth. Mar; 2008 18(3):208-16. [PubMed: 18230063]

27. Hill KD, Lim DS, Everett AD, Ivy DD, Moore JD. Assessment of pulmonary hypertension in the pediatric catheterization laboratory: current insights from the Magic registry. Catheterization and cardiovascular interventions : Official Journal of the Society for Cardiac Angiography \& Interventions. Nov 15; 2010 76(6):865-73.

28. Barst RJ, Maislin G, Fishman AP. Vasodilator therapy for primary pulmonary hypertension in children. Circulation. 1999; 99(9):1197-208. [PubMed: 10069788]

29. Barst RJ, Rubin LJ, Long WA, McGoon MD, Rich S, Badesch DB, et al. A comparison of continuous intravenous epoprostenol (prostacyclin) with conventional therapy for primary pulmonary hypertension. The Primary Pulmonary Hypertension Study Group. N Engl J Med. 1996; 334(5):296-302. [PubMed: 8532025] 
30. Barst R. How has epoprostenol changed the outcome for patients with pulmonary arterial hypertension? Int J Clin Pract Suppl. Nov; 2010 64(168):23-32. [PubMed: 20939843]

31. Doran AK, Ivy DD, Barst RJ, Hill N, Murali S, Benza RL. Guidelines for the prevention of central venous catheter-related blood stream infections with prostanoid therapy for pulmonary arterial hypertension. Int J Clin Pract Suppl. Jul.2008 (160):5-9. [PubMed: 18638170]

32. Ivy DD, Calderbank M, Wagner BD, Dolan S, Nyquist AC, Wade M, et al. Closed-hub systems with protected connections and the reduction of risk of catheter-related bloodstream infection in pediatric patients receiving intravenous prostanoid therapy for pulmonary hypertension. Infect Control Hosp Epidemiol. Sep; 2009 30(9):823-9. [PubMed: 19637961]

33. Ivy DD, Doran A, Claussen L, Bingaman D, Yetman A. Weaning and discontinuation of epoprostenol in children with idiopathic pulmonary arterial hypertension receiving concomitant bosentan. Am J Cardiol. Apr 1; 2004 93(7):943-6. [PubMed: 15050507]

34. Melnick L, Barst RJ, Rowan CA, Kerstein D, Rosenzweig EB. Effectiveness of transition from intravenous epoprostenol to oral/inhaled targeted pulmonary arterial hypertension therapy in pediatric idiopathic and familial pulmonary arterial hypertension. Am J Cardiol. May 15; 2010 105(10):1485-9. [PubMed: 20451700]

35. Tissot C, Beghetti M. Review of inhaled iloprost for the control of pulmonary artery hypertension in children. Vasc Health Risk Manag. 2009; 5(1):325-31. [PubMed: 19436672]

36. Ivy DD, Doran AK, Smith KJ, Mallory GB Jr. Beghetti M, Barst RJ, et al. Short-and long-term effects of inhaled iloprost therapy in children with pulmonary arterial hypertension. J Am Coll Cardiol. Jan 15; 2008 51(2):161-9. [PubMed: 18191742]

37. Limsuwan A, Wanitkul S, Khosithset A, Attanavanich S, Samankatiwat P. Aerosolized iloprost for postoperative pulmonary hypertensive crisis in children with congenital heart disease. Int $\mathbf{J}$ Cardiol. Dec 18.2007

38. Simonneau G, Barst RJ, Galie N, Naeije R, Rich S, Bourge RC, et al. Continuous subcutaneous infusion of treprostinil, a prostacyclin analogue, in patients with pulmonary arterial hypertension: a double-blind, randomized, placebo-controlled trial. Am J Respir Crit Care Med. Mar 15; 2002 165(6):800-4. [PubMed: 11897647]

39. Levy M, Celermajer DS, Bourges-Petit E, Del Cerro MJ, Bajolle F, Bonnet D. Add-on therapy with subcutaneous treprostinil for refractory pediatric pulmonary hypertension. The Journal of pediatrics. Apr; 2011 158(4):584-8. [PubMed: 21035821]

40. Ivy DD, Claussen L, Doran A. Transition of stable pediatric patients with pulmonary arterial hypertension from intravenous epoprostenol to intravenous treprostinil. Am J Cardiol. Mar 1; 2007 99(5):696-8. [PubMed: 17317374]

41. Rosenzweig E, Krishnan U, Takatsuki S, Kerstein D, Calderbank M, Ivy DD. Inhaled treprostinil in pediatric pulmonary arterial hypertension. Am J Respir Crit Care Med. 2011; 183:A6143.

42. Rubin LJ, Badesch DB, Barst RJ, Galie N, Black CM, Keogh A, et al. Bosentan therapy for pulmonary arterial hypertension. N Engl J Med. Mar 21; 2002 346(12):896-903. [PubMed: 11907289]

43. Barst RJ, Ivy D, Dingemanse J, Widlitz A, Schmitt K, Doran A, et al. Pharmacokinetics, safety, and efficacy of bosentan in pediatric patients with pulmonary arterial hypertension. Clin Pharmacol Ther. Apr; 2003 73(4):372-82. [PubMed: 12709727]

44. Beghetti M. Bosentan in pediatric patients with pulmonary arterial hypertension. Curr Vasc Pharmacol. Apr; 2009 7(2):225-33. [PubMed: 19356006]

45. Beghetti M, Hoeper MM, Kiely DG, Carlsen J, Schwierin B, Segal ES, et al. Safety experience with bosentan in 146 children 2-11 years old with pulmonary arterial hypertension: results from the European Postmarketing Surveillance program. Pediatr Res. Aug; 2008 64(2):200-4. [PubMed: 18414142]

46. Maiya S, Hislop AA, Flynn Y, Haworth SG. Response to bosentan in children with pulmonary hypertension. Heart. May; 2006 92(5):664-70. [PubMed: 16216850]

47. Rosenzweig EB, Ivy DD, Widlitz A, Doran A, Claussen LR, Yung D, et al. Effects of long-term bosentan in children with pulmonary arterial hypertension. J Am Coll Cardiol. Aug 16; 2005 46(4):697-704. [PubMed: 16098438] 
48. Hislop AA, Moledina S, Foster H, Schulze-Neick I, Haworth SG. Long-term efficacy of bosentan in treatment of pulmonary arterial hypertension in children. Eur Respir J. Jul; 2011 38(1):70-7. [PubMed: 21177841]

49. Ivy DD, Rosenzweig EB, Lemarie JC, Brand M, Rosenberg D, Barst RJ. Long-term outcomes in children with pulmonary arterial hypertension treated with bosentan in real-world clinical settings. Am J Cardiol. Nov 1; 2010 106(9):1332-8. [PubMed: 21029834]

50. Beghetti M, Haworth SG, Bonnet D, Barst RJ, Acar P, Fraisse A, et al. Pharmacokinetic and clinical profile of a novel formulation of bosentan in children with pulmonary arterial hypertension: the FUTURE-1 study. Br J Clin Pharmacol. Dec; 2009 68(6):948-55. [PubMed: 20002090]

51. Galie N, Beghetti M, Gatzoulis MA, Granton J, Berger RM, Lauer A, et al. Bosentan therapy in patients with Eisenmenger syndrome: a multicenter, double-blind, randomized, placebo-controlled study. Circulation. Jul 4; 2006 114(1):48-54. [PubMed: 16801459]

52. Dimopoulos K, Inuzuka R, Goletto S, Giannakoulas G, Swan L, Wort SJ, et al. Improved survival among patients with Eisenmenger syndrome receiving advanced therapy for pulmonary arterial hypertension. Circulation. Jan 5; 2010 121(1):20-5. [PubMed: 20026774] * Use of advanced therapies in adults with Eisenmenger syndrome is associated with improved survival.

53. Galie N, Badesch D, Oudiz R, Simonneau G, McGoon MD, Keogh AM, et al. Ambrisentan therapy for pulmonary arterial hypertension. J Am Coll Cardiol. Aug 2; 2005 46(3):529-35. [PubMed: 16053970]

54. Ivy DD, Rosenzweig EB, Calderbank M, Coleman B, Miller-Reed K, Geppner J. Pharmacokinetics and safety of ambrisentan in pediatric patients with pulmonary arterial hypertension. Am J Respir Crit Care Med. 2010; 181:A3330.

55. Galie N, Ghofrani HA, Torbicki A, Barst RJ, Rubin LJ, Badesch D, et al. Sildenafil citrate therapy for pulmonary arterial hypertension. N Engl J Med. Nov 17; 2005 353(20):2148-57. [PubMed: 16291984]

56. Karatza AA, Bush A, Magee AG. Safety and efficacy of sildenafil therapy in children with pulmonary hypertension. Int J Cardiol. Apr 20; 2005 100(2):267-73. [PubMed: 15823634]

57. Mourani PM, Sontag MK, Ivy DD, Abman SH. Effects of Long-Term Sildenafil Treatment for Pulmonary Hypertension in Infants with Chronic Lung Disease. J Pediatr. Oct 23.2009 154:379_ 84. [PubMed: 18950791]

58. Humpl T, Reyes JT, Erickson S, Armano R, Holtby H, Adatia I. Sildenafil therapy for neonatal and childhood pulmonary hypertensive vascular disease. Cardiology in the Young. Apr; 2011 21(2): 187-93. [PubMed: 21138617]

59. Namachivayam P, Theilen U, Butt WW, Cooper SM, Penny DJ, Shekerdemian LS. Sildenafil prevents rebound pulmonary hypertension after withdrawal of nitric oxide in children. Am J Respir Crit Care Med. Nov 1; 2006 174(9):1042-7. [PubMed: 16917115]

60. Atz Am LA, Fairbrother DL, Uber WE, Bradley SM. Sildenafil augments the effect of inhaled nitric oxide for postoperative pulmonary hypertensive crisis. J Thorac Cardiovasc Surg. 2002; 124:628-9. [PubMed: 12202882]

61. Barst RJ, Ivy DD, Gaitan G, Szatmari A, Rudzinski A, Garcia AE, et al. A Randomized, DoubleBlind, Placebo-Controlled, Dose-Ranging Study of Oral Sildenafil Citrate in Treatment-Naive Children With Pulmonary Arterial Hypertension. Circulation. 2011 In Print. **The first randomized trial of targeted $\mathrm{PH}$ therapy in children. Although the primary exercise endpoint did not meet statistical significance, dose-related improvements in hemodynamics and exercise capacity were seen. Initial long term follow-up of treatment naïve children receiving sildenafil monotherapy showed increased mortality with the high dose at 3 years.

62. Schulze-Neick I, Hartenstein P, Li J, Stiller B, Nagdyman N, Hubler M, et al. Intravenous sildenafil is a potent pulmonary vasodilator in children with congenital heart disease. Circulation. Sep 9; 2003 108(Suppl 1):II167-73. [PubMed: 12970227]

63. Stocker C, Penny DJ, Brizard CP, Cochrane AD, Soto R, Shekerdemian LS. Intravenous sildenafil and inhaled nitric oxide: a randomised trial in infants after cardiac surgery. Intensive Care Med. Nov; 2003 29(11):1996-2003. [PubMed: 14530859] 
64. Steinhorn RH, Kinsella JP, Pierce C, Butrous G, Dilleen M, Oakes M, et al. Intravenous sildenafil in the treatment of neonates with persistent pulmonary hypertension. The Journal of Pediatrics. Dec; 2009 155(6):841-7. [PubMed: 19836028] * Dosing study of intravenous sildenafil showing improvement in oxygenation index in persistent pulmonary hypertension of the newborn.

65. Fraisse A, Butrous G, Taylor MB, Oakes M, Dilleen M, Wessel DL. Intravenous sildenafil for postoperative pulmonary hypertension in children with congenital heart disease. Intensive Care Med. Mar; 2011 37(3):502-9. [PubMed: 21069290]

66. Galie N, Brundage BH, Ghofrani HA, Oudiz RJ, Simonneau G, Safdar Z, et al. Tadalafil therapy for pulmonary arterial hypertension. Circulation. Jun 9; 2009 119(22):2894-903. [PubMed: 19470885]

67. Rosenzweig EB. Tadalafil for the treatment of pulmonary arterial hypertension. Expert Opin Pharmacother. Jan; 2010 11(1):127-32. [PubMed: 20001434]

68. Takatsuki S, Calderbank M, Ivy DD. Initial experience with tadalafil in pediatric pulmonary arterial hypertension. Pediatric Cardiology. 2011 In Print.

69. Ghofrani HA, Seeger W, Grimminger F. Imatinib for the treatment of pulmonary arterial hypertension. N Engl J Med. Sep 29; 2005 353(13):1412-3. [PubMed: 16192491]

70. Ghofrani HA, Morrell NW, Hoeper MM, Olschewski H, Peacock AJ, Barst RJ, et al. Imatinib in pulmonary arterial hypertension patients with inadequate response to established therapy. American Journal of Respiratory and Critical Care Medicine. Nov 1; 2010 182(9):1171-7. [PubMed: 20581169]

71. Zhao YD, Courtman DW, Deng Y, Kugathasan L, Zhang Q, Stewart DJ. Rescue of monocrotalineinduced pulmonary arterial hypertension using bone marrow-derived endothelial-like progenitor cells: efficacy of combined cell and eNOS gene therapy in established disease. Circ Res. Mar 4; 2005 96(4):442-50. [PubMed: 15692087]

72. Stewart DJ, Zhao YD, Courtman DW. Cell therapy for pulmonary hypertension: what is the true potential of endothelial progenitor cells? Circulation. Mar 30; 2004 109(12):e172-3. [PubMed: 15051655]

73. Yeager ME, Nguyen CM, Belchenko DD, Colvin KL, Takatsuki S, Ivy DD, et al. Circulating Fibrocytes Are Increased in Children and Young Adults with Pulmonary Hypertension. The European Respiratory Journal. Jun 23.2011 In Print.

74. Belik J. Riociguat, an oral soluble guanylate cyclase stimulator for the treatment of pulmonary hypertension. Curr Opin Investig Drugs. Sep; 2009 10(9):971-9.

75. Ghofrani HA, Hoeper MM, Halank M, Meyer FJ, Staehler G, Behr J, et al. Riociguat for chronic thromboembolic pulmonary hypertension and pulmonary arterial hypertension: a phase II study. The European Respiratory Journal. Oct; 2010 36(4):792-9. [PubMed: 20530034]

76. Grimminger F, Weimann G, Frey R, Voswinckel R, Thamm M, Bolkow D, et al. First acute haemodynamic study of soluble guanylate cyclase stimulator riociguat in pulmonary hypertension. Eur Respir J. Apr; 2009 33(4):785-92. [PubMed: 19129292]

77. Schermuly RT, Janssen W, Weissmann N, Stasch JP, Grimminger F, Ghofrani HA. Riociguat for the treatment of pulmonary hypertension. Expert Opin Investig Drugs. Apr; 2011 20(4):567-76.

78. Morrison K, Ernst R, Hess P, Studer R, Clozel M. Selexipag: a selective prostacyclin receptor agonist that does not affect rat gastric function. J Pharmacol Exp Ther. Oct; 2010 335(1):249-55. [PubMed: 20660124]

79. Sidharta PN, van Giersbergen PL, Halabi A, Dingemanse J. Macitentan: entry-into-humans study with a new endothelin receptor antagonist. Eur J Clin Pharmacol. May 4; 2011 67(10):977-84. [PubMed: 21541781] 


\section{Key points}

1. A pediatric pulmonary hypertensive vascular disease classification has been developed that incorporates abnormalities of lung growth and development as well as syndromes frequently contributing to PAH

2. The incidence of Idiopathic PAH is lower in children than adults and is less than 1 case per million

3. Therapy for PAH in adults is based on evidence whereas therapy in children is based mainly on experience.

4. Long-term, high dose sildenafil monotherapy in treatment naïve children with PAH has been associated with increased mortality

5. Novel therapies are being developed to reverse remodeling in PAH 


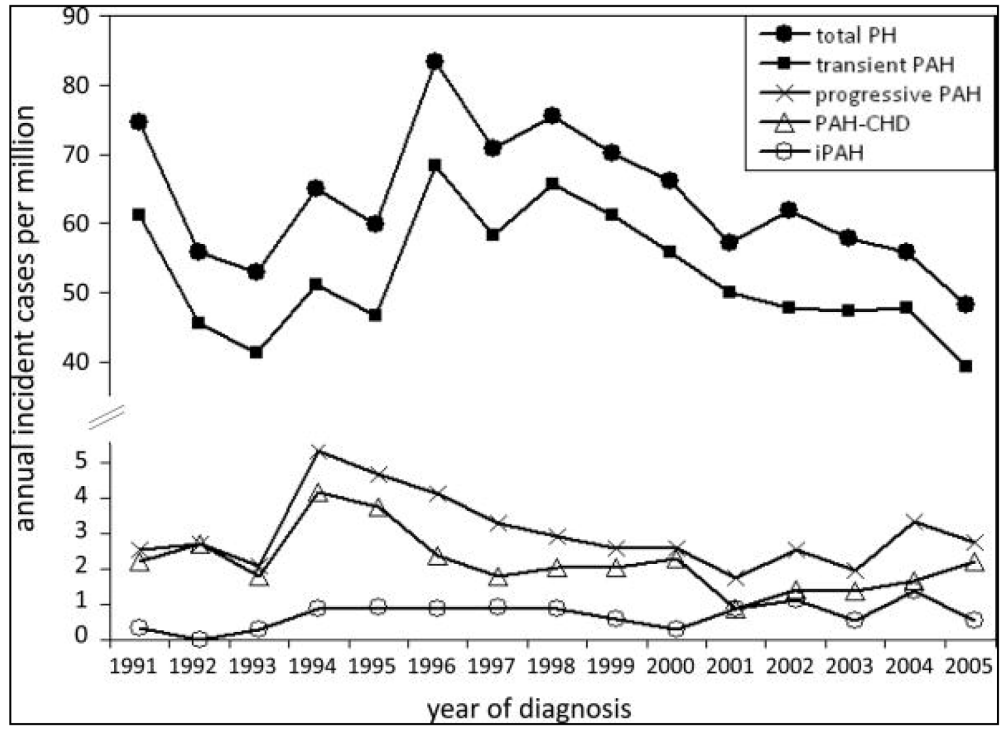

Figure 1.

Annual incidence rates for pediatric pulmonary hypertension in the Netherlands. PH indicates pulmonary hypertension; PAH, pulmonary arterial hypertension; PAH-CHD, PAH associated with congenital heart defects; and iPAH, idiopathic PAH.

Source: [7] Van Loon RL, et al. Circulation. 2011 Sep 26;124:1755-64. 
a

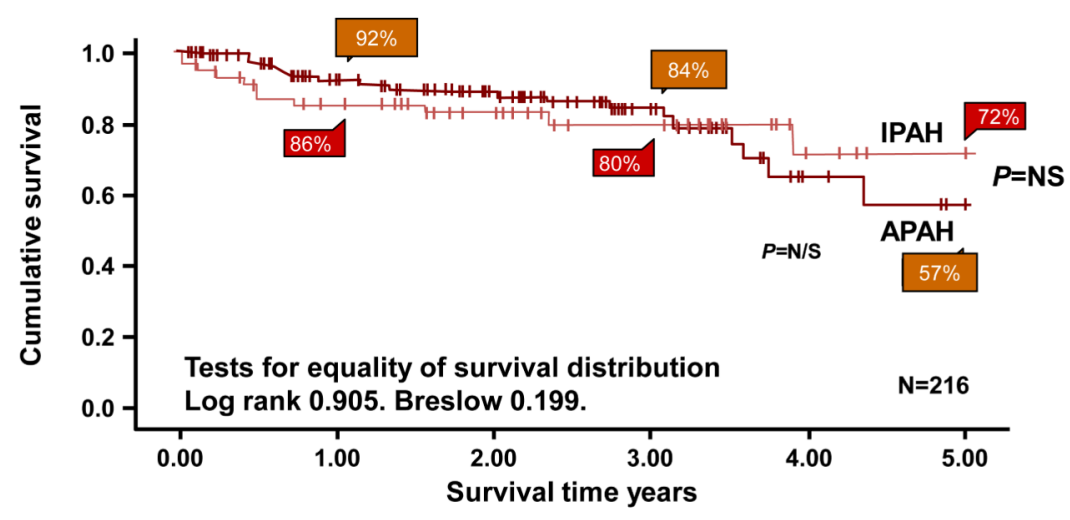

b

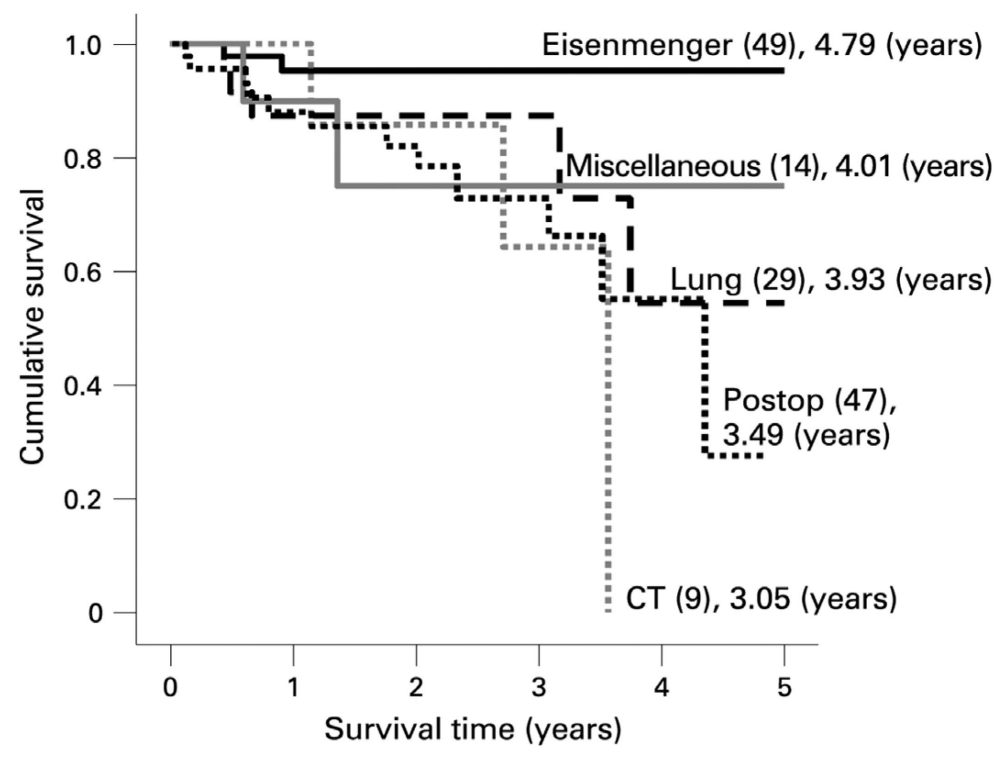

$\mathrm{CT}=$ Connective $\mathrm{Tissue}$

Figure 2.

Survival curves for idiopathic pulmonary arterial hypertension (IPAH) and associated pulmonary arterial hypertension (APAH) cases censored for time in the study and for transplantation. There was no significant difference between the two groups. B. Survival curves for the subgroups within the associated pulmonary arterial hypertension (APAH) group. The number in each group (brackets) and the predicted survival out of a possible 5 years are shown. CT: Connective Tissue.

Source: [9] Haworth, SG et al. Heart 2009;95:312-317 


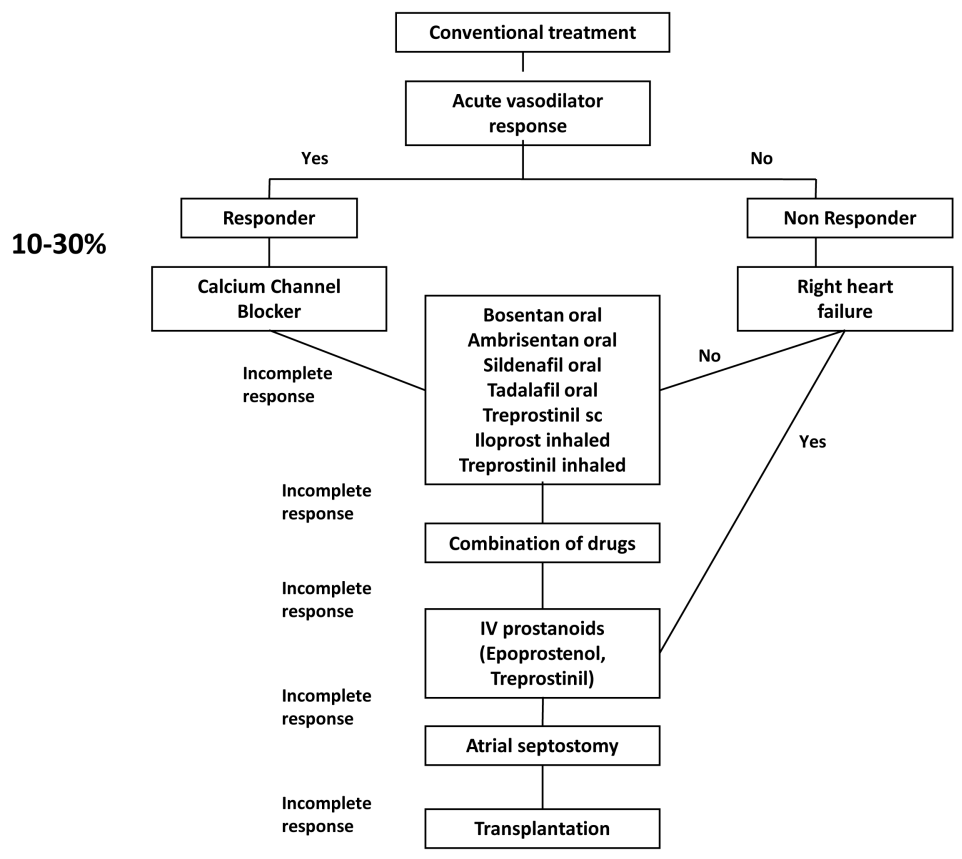

$70-90 \%$

Figure 3.

Treatment algorithm in children with severe pulmonary arterial hypertension.

Source: [14] Tissot C, et al. J Pediatr. 2010;157:528-532 


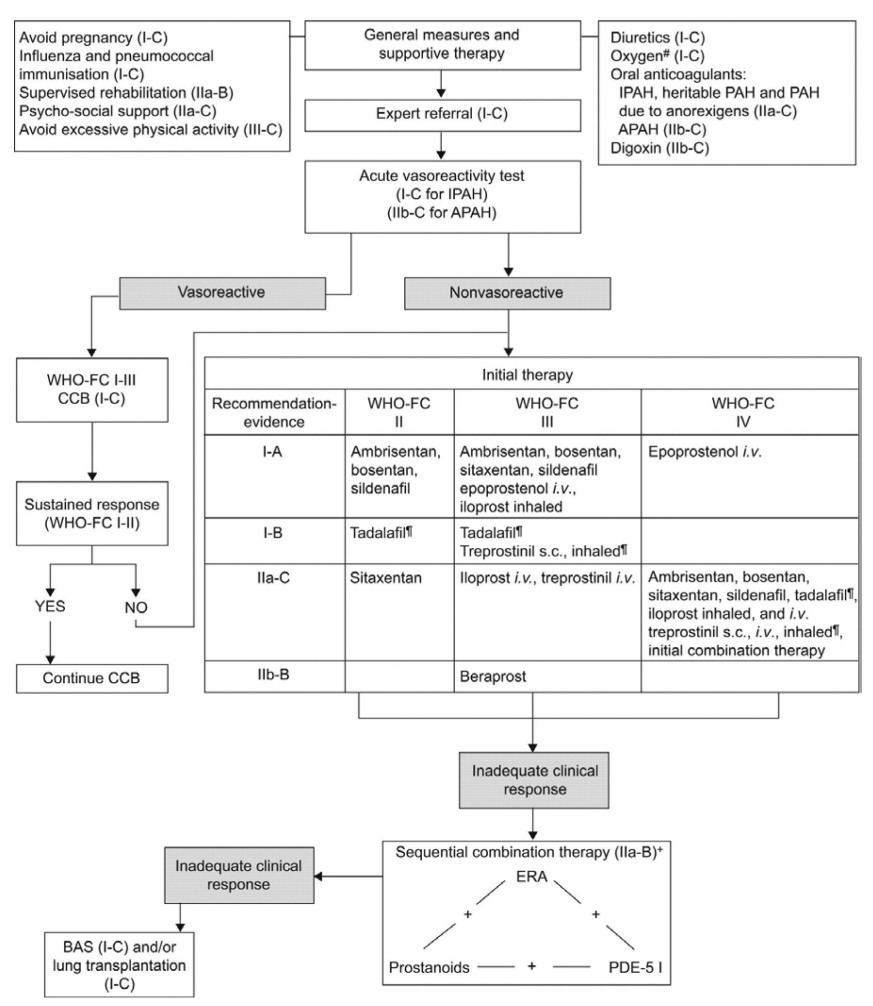

Figure 4.

Evidence-based treatment algorithm for pulmonary arterial hypertension adults (for group 1 patients only). APAH: associated pulmonary arterial hypertension; BAS: balloon atrial septostomy; CCB: calcium channel blocker; ERA: endothelin receptor antagonist; IPAH: idiopathic pulmonary arterial hypertension; PAH: pulmonary arterial hypertension; PDE-5 I: phosphodiesterase type-5 inhibitor; s.c.: subcutaneously; WHO-FC: World Health

Organization functional class. ${ }^{\#}$ : to maintain arterial blood $\mathrm{O}_{2}$ pressure $>60 \mathrm{mmHg}$; ${ }^{\mathrm{II}}$ : under regulatory review in the European Union; ${ }^{+}$: IIa-C for WHO-FC II.

Source: [16] Galie N et al Eur Heart J. 2009;30(20):2493-2537. 

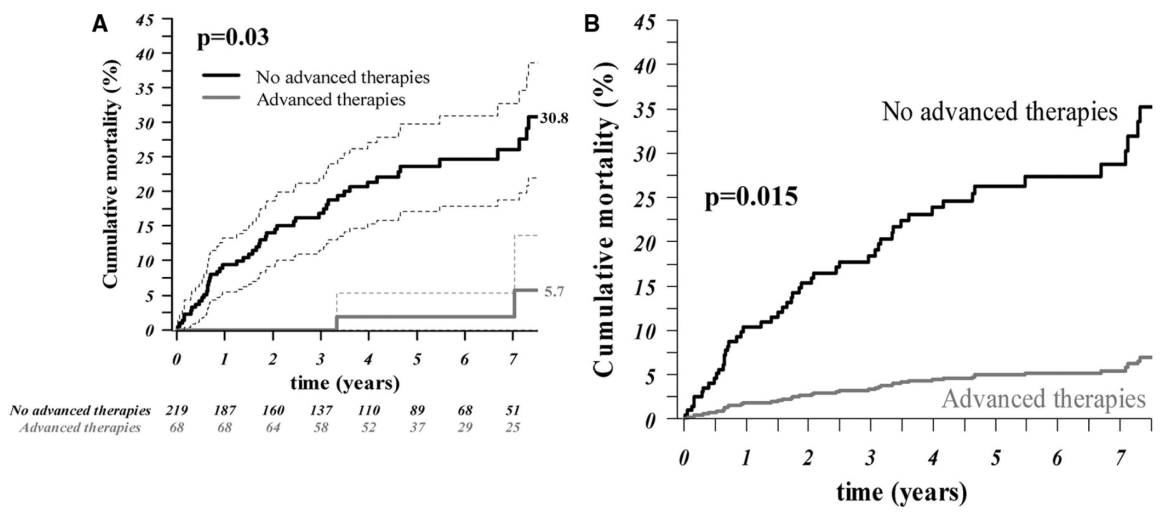

Figure 5.

A. Unadjusted survival rate curves (with $95 \%$ CIs) by treatment with advanced therapies in adults with Eisenmenger syndrome (AT $(\mathrm{n}=287)$. $P$ value refers to Cox model. $B$. Adjusted survival rate curves, based on the propensity score-adjusted Cox model, of patients within the third propensity score quartile, with and without advanced therapy.

Source: [52] Dimopoulos K et al; Circulation. 2010;121:20-25 


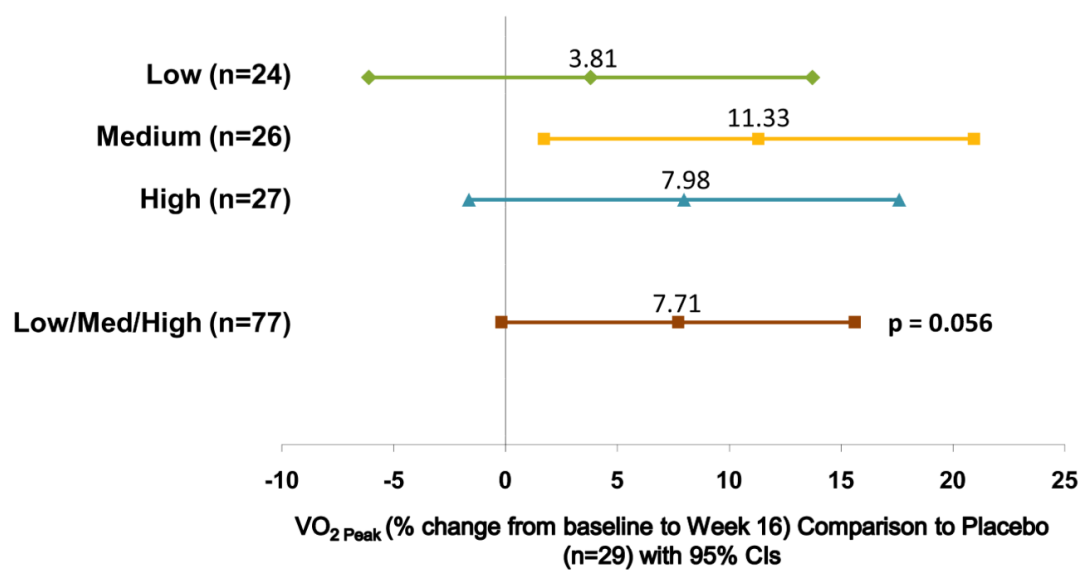

Figure 6.

Placebo-adjusted percent change in peak $\mathrm{VO}_{2}$ by cardiopulmonary exercise after 16 weeks of sildenafil or placebo in a randomized, double-blind, placebo-controlled, dose-ranging study of oral sildenafil citrate in treatment-naive children with pulmonary arterial hypertension.

Source: [9] Barst RJ, Ivy DD, et al. Circulation. 2011;In Print. 
Table 1

Updated WHO clinical classification of pulmonary hypertension (Dana Point, 2008)

\begin{tabular}{|l|ll}
\hline & \multicolumn{3}{|l}{ Pulmonary arterial hypertension $(\mathbf{P A H})$} \\
1.1 & Idiopathic \\
1.2 & Heritable \\
1.2 .1 & BMPR2 \\
1.2 .2 & ALK1, endoglin (with or without hereditary hemorrhagic telangiectasia) \\
1.2 .3 & Unknown \\
1.3 & Drug- and toxin-induced \\
1.4 & Associated with (APAH) \\
1.4 .1 & Connective tissue diseases \\
1.4 .2 & HIV infection \\
1.4 .3 & Portal hypertension \\
1.4 .4 & Congenital heart disease \\
1.4 .5 & Schistosomiasis \\
1.4 .6 & Chronic hemolytic anemia \\
1.5 & Persistent pulmonary hypertension of the newborn
\end{tabular}

$1^{\prime} \mid$ Pulmonary veno-occlusive disease and/or pulmonary capillary hemangiomatosis

2 Pulmonary hypertension due to left heart disease

$2.1 \quad$ Systolic dysfunction

2.2 Diastolic dysfunction

$2.3 \quad$ Valvular disease

3 Pulmonary hypertension due to lung diseases and/or hypoxemia

3.1 Chronic obstructive pulmonary disease

3.2 Interstitial lung disease

3.3 Other pulmonary diseases with mixed restrictive and obstructive pattern

3.4 Sleep-disordered breathing

3.5 Alveolar hypoventilation disorders

3.6 Chronic exposure to high altitudes

3.7 Developmental abnormalities

4 Chronic thromboembolic pulmonary hypertension

5 Pulmonary hypertension with unclear and/or multifactorial mechanisms

5.1 Hematologic disorders: myeloproliferative disorders, splenectomy

5.2 Systemic disorders: sarcoidosis, pulmonary Langerhans cell histiocytosis, lymphangioleiomyomatosis, neurofibromatosis, vasculitis

5.3 Metabolic disorders: glycogen storage disease, Gaucher disease, thyroid disorders

5.4 Others: tumoral obstruction, fibrosing mediastinitis, chronic renal failure on dialysis

$A L K 1=$ activin receptor-like kinase 1 gene; $\mathrm{APAH}=$ associated pulmonary arterial hypertension; $B M P R 2=$ bone morphogenetic protein receptor, type 2; HIV = human immunodeficiency virus; $\mathrm{WHO}=$ World Health Organization

Simonneau G, Robbins IM, Beghetti M, et al. Updated clinical classification of pulmonary hypertension. J Am Coll Cardiol. 2009;54(suppl 1):S43S54. 
Table 2

The broad schema of 10 basic categories of Pediatric Pulmonary Hypertensive Vascular Disease

\begin{tabular}{lll}
\hline $\mathbf{1}$ & Prenatal or developmental pulmonary hypertensive vascular disease \\
$\mathbf{2}$ & Perinatal pulmonary vascular maladaptation \\
$\mathbf{3}$ & Pediatric cardiovascular disease \\
$\mathbf{4}$ & Bronchopulmonary dysplasia \\
$\mathbf{5}$ & Isolated pediatric pulmonary hypertensive vascular disease (isolated pediatric PAH) \\
$\mathbf{6}$ & Multifactorial pulmonary vascular disease in congenital malformation syndromes \\
$\mathbf{7}$ & Pediatric lung disease \\
$\mathbf{8}$ & Pediatric thromboembolic disease \\
$\mathbf{9}$ & Pediatric hypobaric hypoxic exposure \\
$\mathbf{1 0}$ & Pulmonary vascular disease associated with other system disorders \\
&
\end{tabular}

Cerro MJ, Abman S, Diaz G, Freudenthal AH, Freudenthal F, Harikrishnan S, et al. A consensus approach to the classification of pediatric pulmonary hypertensive vascular disease: Report from the PVRI Pediatric Taskforce, Panama 2011. Pulm Circ. 2011;1(2):286-98. 


\section{Table 3}

Sildenafil Thrice Daily Dose in the STARTS-1 trial

\begin{tabular}{lccc}
\hline & \multicolumn{3}{c}{ Sildenafil Dose (mg) } \\
\cline { 2 - 4 } Body Weight $(\mathbf{k g})$ & Low & Medium & High \\
\hline$\geq 8$ to 20 & $\mathrm{NA}^{\dagger}$ & $10^{\dagger}$ & 20 \\
$>20$ to 45 & 10 & 20 & 40 \\
$>45$ & 10 & 40 & 80 \\
\hline
\end{tabular}

${ }^{\dagger}$ Modeling of the plasma concentrations for each dose level showed that the low and medium doses were predicted to be similar for the 8- to 20 -kg patients (ie, patients would receive the same dose because of the available tablet strengths); consequently there was no low dose for this group.

Barst RJ, Ivy DD, et al. Circulation. 2011;In Print. 